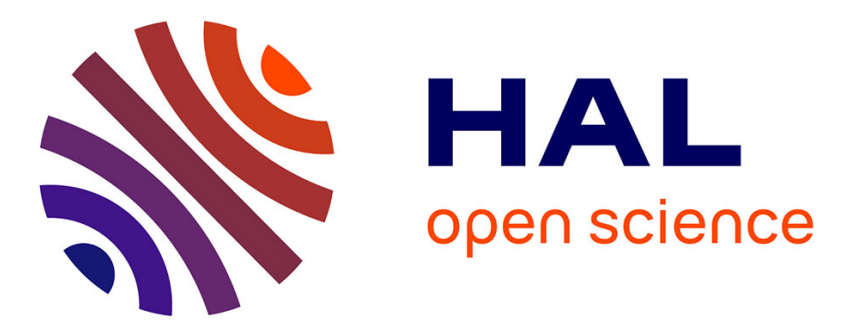

\title{
Peripartum bleeding management in a patient with CalDAG-GEFI deficiency
}

\author{
M. Canault, P. Saultier, Sixtine Faure, M. Poggi, A. Nurden, P. Nurden, P. \\ Morange, Marie-Christine Alessi, J-C. Gris
}

\section{- To cite this version:}

M. Canault, P. Saultier, Sixtine Faure, M. Poggi, A. Nurden, et al.. Peripartum bleeding management in a patient with CalDAG-GEFI deficiency. Haemophilia, 2017, 23 (6), pp.e533-e535. 10.1111/hae.13352 . hal-01753798

\section{HAL Id: hal-01753798 \\ https://hal-amu.archives-ouvertes.fr/hal-01753798}

Submitted on 6 Apr 2018

HAL is a multi-disciplinary open access archive for the deposit and dissemination of scientific research documents, whether they are published or not. The documents may come from teaching and research institutions in France or abroad, or from public or private research centers.
L'archive ouverte pluridisciplinaire HAL, est destinée au dépôt et à la diffusion de documents scientifiques de niveau recherche, publiés ou non, émanant des établissements d'enseignement et de recherche français ou étrangers, des laboratoires publics ou privés. 


\section{Peripartum bleeding management in a patient with CaIDAG-GEFI deficiency}

Matthias Canault ${ }^{1}$, Paul Saultier ${ }^{1}$, Sixtine Fauré ${ }^{1}$, Marjorie Poggi ${ }^{1}$, Alan T Nurden ${ }^{2}$, Paquita Nurden $^{2}$, Pierre-Emmanuel Morange ${ }^{1,3}$, Marie-Christine Alessi ${ }^{1,3}{ }^{*}$, Jean-Christophe Gris ${ }^{4 *}$

${ }^{1}$ Aix Marseille Univ, INSERM, INRA, NORT, Marseille, France

${ }^{2}$ Institut-Hospitalo-Universitaire LIRYC, Plateforme Technologique et d'Innovation Biomédicale, Hôpital Xavier Arnozan, Pessac, France

${ }^{3}$ APHM, CHU Timone, French Reference Centre for Rare Platelet Disorders, Marseille, France.

${ }^{4}$ Laboratoire d'hématologie, Groupe Hospitalo-Universitaire Caremeau, Nîmes, France

* These authors contributed equally to this study

Correspondence to:

Matthias Canault

UMR Inserm 1062, INRA 1260, Aix-Marseille Univ

Nutrition, Obesity and Risk of Thrombosis (NORT) laboratory

Faculté de Médecine Timone, 27 boulevard Jean-Moulin

13385 Marseille Cedex 05

matthias.canault@univ-amu.fr

Tel: +33491324507

Fax: +33491254336

\section{Essentials}

- Some platelet disorders increase risk of haemorrhage during pregnancy and delivery.

- Management of bleeding diathesis during the course of pregnancy in CalDAG-GEFI deficiency.

- Severe bleeding occurred in the postpartum period similar to that in women with Glanzmann's thrombasthenia.

- A planned bleeding prevention strategy is required for pregnant women with CalDAGGEFI deficiency.

Word count: 955 
To the editor,

Pregnant women with inherited platelet disorders are at high risk of life-threatening haemorrhage during delivery. Foetuses and newborns can also be affected, and be at risk of bleeding complications $(1,2)$. Here we describe bleeding diathesis and its management during the course of pregnancy in a young woman with severe mucocutaneous bleeding and platelet dysfunction caused by calcium and diacylglycerol-guanine exchange factor I (CalDAG-GEFI) deficiency recently characterised by several groups (3-6). The patient was explored after informed written consent was obtained, in accordance with the Declaration of Helsinki.

The propositus was born in 1994 from asymptomatic consanguineous parents (cousins). She experienced easy bruising and recurrent epistaxis from early childhood (Fig. 1A) with an International Society on Thrombosis and Haemostasis (ISTH) bleeding score (7) of 5. She carried a homozygous frameshift mutation c.199_200delAA (p.N67Lfs*24) within the CalDAG-GEFI coding gene, RASGRP2 (6). Westbury et al. recently described her clinical features and platelet phenotypes, emphasising a platelet aggregation defect after stimulation with intermediate- and low-dose agonists.

Western-blot analysis revealed absence of CalDAG-GEFI in the patient's platelets (Fig. 1B) and in GripTite 293 MSR cells expressing the p.L67 variant compared with the p.N67 (wildtype) and the p.G248W (previously reported (3)) variants (Fig. 1C).

Between ages 5 and 11 years the propositus was repeatedly hospitalised for intractable mucocutaneous bleeding, with sometimes acute anaemia requiring platelet/red blood cell (RBC) transfusions, recombinant factor VIIa (rFVIIa) injection $(90 \mu \mathrm{g} / \mathrm{kg})$, tranexamic acid and iron supplementation (Fig. 1A). At menarche (age 11 years), she experienced severe menorrhagia, treated with tranexamic acid. Severe autoimmune thrombocytopenia $(6 \mathrm{G} / 1$ with strongly positive anti-GPIIbIIIa (anti- $\alpha_{\mathrm{II}} \beta_{3}$ integrin) autoantibodies) was concomitantly 
evidenced. Evans' syndrome was characterised one year later (haemoglobin $63 \mathrm{~g} / \mathrm{l}$, platelet count $59 \mathrm{G} / 1$ ) with further diagnosis of systemic lupus erythematosus (SLE) complicated by lupus nephropathy at age 13 years. She was treated with initial $\gamma$-globulin infusion, corticosteroids, hydroxychloroquine and enalapril.

At age 15 years she was hospitalised for acute anaemia (46 g/l haemoglobin) due to severe menorrhagia. Her platelet count was $500 \mathrm{G} / 1$, and bleeding was treated with platelet/RBC transfusions and nomegestrol. Treatment on exit was iron supplementation, prednisone, enalapril, and hydroxochloroquine.

At age 19 years she received progestin oral contraception to treat hypermenorrhea. Her chronic treatment was maintained.

A first pregnancy was diagnosed a few months later. She displayed normal blood pressure values and no sign of oedema. Platelet count was $252 \mathrm{G} / 1$, and she tested positively for antinuclear antibodies 1/320, and negative for anti-DNA and antiphospholipid antibodies. Creatinine level was $52 \mu \mathrm{M}$ (normal range $45-90 \mu \mathrm{M}$ ) with no proteinuria. The patient had a monthly follow-up, without emergence of any abnormal symptom (bleeding, SLE flare, cytopenia or manifestation of renal disease).

She was hospitalised for spontaneous onset of labour at 38 weeks plus 6 days (platelet count $277 \mathrm{G} / \mathrm{l}$, haemoglobin $145 \mathrm{~g} / \mathrm{l})$. Spinal or epidural anaesthesia was contraindicated, and patient-controlled analgesia with remifentanil was initiated. As labour progressed, prophylactic transfusion of 6 platelet concentrates and continuous intravenous tranexamic acid infusion $\left(10 \mathrm{mg} \cdot \mathrm{kg}^{-1}\right.$ bolus, then $\left.1 \mathrm{mg} / \mathrm{kg} / \mathrm{h}\right)$ were prescribed. She gave birth after $8 \mathrm{~h}$ of labour by vaginal delivery, to a healthy male newborn with normal neonatal blood cell counts. Artificial placental delivery had to be performed under general anaesthesia. Sulprostone was used to reverse uterus atony and prevent postpartum haemorrhage. No maternal or neonate bleeding was evidenced. One prophylactic transfusion of 6 platelet concentrates was 
performed early post-delivery. The patient was monitored for 5 days, and was released from hospital without any haemostatic maintenance treatment.

Severe metrorrhagia occurred on day 11 post partum. A single emergency transfusion of 6 platelet concentrates was administered together with a continuous tranexamic acid infusion (Fig. 1A), resulting in prompt positive clinical effects. The patient left the hospital on day 13 post partum; her treatment was prednisone $(10 \mathrm{mg} / \mathrm{d})$, hydroxochloroquine $(400 \mathrm{mg} / \mathrm{d})$, oral tranexamic acid ( $1 \mathrm{~g}$ each $8 \mathrm{~h}$ for 3 days).

She underwent an emergency hospitalisation 38 days post partum for a severe haemorrhagic first post-pregnancy menstrual period with expulsion of clots by the vaginal route. Platelet count was within normal ranges. Platelets and RBC transfusions, intravenous tranexamic acid and fluid infusions allowed haemodynamic stabilisation, but showed moderate haemostatic efficacy. A single rFVIIa injection $(90 \mu \mathrm{g} / \mathrm{kg})$ stopped abnormal bleeding. The patient left the hospital 4 days later.

This report is the first to describe the management of pregnancy and parturition in a patient with homozygous CalDAG-GEFI deficiency. A deficit in CalDAG-GEFI leads to integrin activation defects (3-5). However, unlike in Glanzmann's thrombasthenia (GT), CalDAGGEFI-deficient platelets achieve full aggregation when stimulated with high doses of strong agonists (TRAP-6 and collagen). This suggests that the risk of bleeding complications in these patients might be lower than in women with GT.

As in other inherited platelet disorders (1), the course of pregnancy in this context was not altered despite the added diagnosis of SLE. Repeated platelet transfusions in the delivery period prevented haemorrhage. Close follow-up and a preventive haemostatic strategy in women with CalDAG-GEFI deficiency are required not only during the primary postpartum period (within $48 \mathrm{~h}$ of birth), but also from $48 \mathrm{~h}$ to several weeks post-birth until menses resume. Maintaining tranexamic acid treatment might be of benefit throughout this period. 
The severe bleeding episode experienced at resumption of menses was only partially controlled by platelet and RBC transfusions. Injection of single-dose rFVIIa demonstrated a significant effect in stopping haemorrhage. Thus rFVIIa may be considered as a strategy to manage the haemorrhagic risk in women with CalDAG-GEFI deficiency at delivery and during the following days.

In conclusion, this case illustrates for the first time that CalDAG-GEFI deficiency carries an increased risk of severe bleeding during the peripartum period. Prolonged monitoring and a planned preventive haemostatic strategy are accordingly required to minimise bleeding in these high-risk pregnant women.

\section{Acknowledgements}

We thank J.P. Balducchi, S. Baron-Joly, N. Catteau, R. Salet, A.L. Ladra-Delenne, R. de Tayrac, S. Ripart, J.M. Ferrer, and L. Mattatia for their expert medical help in the acute and chronic management of the patient. We also thank N. Saut of the Laboratoire d'Hématologie, Hôpital de la Timone, Assistance Publique-Hôpitaux de Marseille) for gene sequencing.

M. Canault and J-C. Gris performed the research, designed the research study, took part in the clinical characterisation of patients, analysed the data and wrote the paper. P. Saultier, S. Faure and M. Poggi performed the research, analysed the data and wrote the paper. A.T. Nurden, P. Nurden, P.E. Morange and M-C. Alessi designed the research study, analysed the data and wrote the paper. The authors have no competing interests

\section{References}

1. Civaschi E, Klersy C, Melazzini F, Pujol-Moix N, Santoro C, Cattaneo M, et al. Analysis of 65 pregnancies in 34 women with five different forms of inherited platelet function disorders. Br J Haematol. 2015 Aug;170(4):559-63. PubMed PMID: 25899604.

2. Noris P, Schlegel N, Klersy C, Heller PG, Civaschi E, Pujol-Moix N, et al. Analysis of 339 pregnancies in 181 women with 13 different forms of inherited thrombocytopenia. Haematologica. 2014 Aug;99(8):1387-94. PubMed PMID: 24763399. PMCID: 4116839. 
3. Canault M, Ghalloussi D, Grosdidier C, Guinier M, Perret C, Chelghoum N, et al. Human CalDAG-GEFI gene (RASGRP2) mutation affects platelet function and causes severe bleeding. The Journal of experimental medicine. 2014 Jun 30;211(7):1349-62. PubMed PMID: 24958846. PMCID: 4076591.

4. Kato H, Nakazawa Y, Kurokawa Y, Kashiwagi H, Morikawa Y, Morita D, et al. Human CalDAG-GEFI deficiency confers severe bleeding tendency and delayed alphaIIbbeta3 activation velocity. Blood. 2016 Sep 23. PubMed PMID: 27663674.

5. Lozano ML, Cook A, Bastida JM, Paul DS, Iruin G, Cid AR, et al. Novel mutations in RASGRP2 encoding for CalDAG-GEFI abrogate Rap1 activation causing platelet dysfunction. Blood. 2016 May 27. PubMed PMID: 27235135.

6. Westbury SK, Canault M, Greene D, Bermejo E, Hanlon K, Lambert MP, et al. Expanded repertoire of RASGRP2 variants responsible for platelet dysfunction and severe bleeding. Blood. 2017 Jun 21. PubMed PMID: 28637664.

7. Rodeghiero F, Tosetto A, Abshire T, Arnold DM, Coller B, James P, et al. ISTH/SSC bleeding assessment tool: a standardized questionnaire and a proposal for a new bleeding score for inherited bleeding disorders. J Thromb Haemost. 2010 Sep;8(9):2063-5. PubMed PMID: 20626619.

8. Siddiq S, Clark A, Mumford A. A systematic review of the management and outcomes of pregnancy in Glanzmann thrombasthenia. Haemophilia. 2011 Sep;17(5):e858-69. PubMed PMID: 21457404.

9. Deng YJ, Huang ZX, Zhou CJ, Wang JW, You Y, Song ZQ, et al. Gene profiling involved in immature CD4+ $\mathrm{T}$ lymphocyte responsible for systemic lupus erythematosus. Molecular immunology. 2006 Mar;43(9):1497-507. PubMed PMID: 16143398.

10. Ishida D, Su L, Tamura A, Katayama Y, Kawai Y, Wang SF, et al. Rap1 signal controls B cell receptor repertoire and generation of self-reactive Bla cells. Immunity. 2006 Apr;24(4):417-27. PubMed PMID: 16618600.

\section{Figure legends}

Figure 1: (A) Evolution of platelet count, haemorrhagic and autoimmune manifestations and haemostatic treatments prior to and during pregnancy/delivery. (B) Representative Westernblot for CalDAG-GEFI in platelet lysates from two healthy subjects (Controls), the patient, her mother and her father. GAPDH expression was used as equal loading and electrophoretic transfer control. (C) Representative Western-blot for CalDAG-GEFI in GripTite ${ }^{\mathrm{TM}} 293$ MSR cells transfected with vectors coding for the wild-type, p.G248W, and p.N67Lfs*24 variants 
171 of CalDAG-GEFI. GAPDH expression was used as equal loading and electrophoretic transfer 172 control. 